\title{
THE SOCIO-ECONOMICS OF COASTAL COMMUNITIES IN SORONG CITY, WEST PAPUA PROVINCE OF INDONESIA
}

\author{
Handayani, Mustasim, Mahmud Amir \\ Sorong Marine and Fisheries Polytechnic, Indonesia
}

\begin{abstract}
This study aims to analyze the socio-economics of coastal communities living coexistent with mangrove ecosystems in the Sub-district of Klamana, Sorong City. The descriptive method was employed along with satellite imagery interpretation, spatial data processing, and analysis using Geographic Information Systems (GIS) to analyze the socio-economic facilities as well as interview and documentation techniques. The results indicated that the level of community education was relatively low as mostly were graduated from elementary school $(55 \%)$ and did not attend any formal education/school (16\%). Their main occupation is traditional fishermen using fishing fleets and nets. The average level of community income is Rp 1,633,824 / month, which is categorized as very low income (poor). They reside in semi-permanent and non-permanent community housing with wooden walls and ground floor. Education, trade and service facilities, health and government facilities, as well as public services, are sufficient and easily accessible by transportation. Financing, however, is a major problem for the community, and motivation to maximize the existing potentials is included in the problem-list as well; thus, so the involvement of the Sorong City Government is highly crucial for the community.
\end{abstract}

\section{KEY WORDS}

Community, social relations, economics, public service.

Generally, socioeconomic studies attempt to describe the socioeconomic conditions of a community (especially in a coastal area) or the position of a person in a community group determined by the type of their economic activity, education, and income. Coastal communities are defined as groups of people who live in coastal areas and whose household financial resources depend on the use of marine and coastal resources as well as environmental, seasonal and market factors (Nikijuluw, 2001; Wahyudin, 2003; Satria, 2004; Purba, 2005). Coastal communities include fishermen, fish cultivators, fishery product processors, and fish traders. Nevertheless, most coastal communities in Indonesia are fishermen; thereby, it is safe to say that they are the main actors using fisheries resources.

The social, economic and cultural systems of coastal communities are strongly influenced by ecological factors of the coastal area in which they live. Therefore, if there is a local ecological change, there will also be changes to the social system of the community. Adaptation to ecological changes is performed by the community to survive. The pattern of community adaptation is related to the pattern of utilizing the potential of coastal and marine resources to meet their needs. Living near the beach for fishing communities is most desirable considering all the aspects of the convenience they can experience in their daily activities. According to Wahyudin (2003), the ease of access for coastal communities, among others, is the ease of accessibility to and from sources of livelihoods which is more secure, considering that most of the coastal communities are fishermen who depend most of their lives on the utilization of nearby fisheries resources such as fishing, cultivation, and others. Another ease of access is to easily meet the needs of personal hygiene (in Indonesia: MCK Mandi Cuci Kakus - taking baths, washing, toilets) and disposing of domestic waste.

Understanding the potential and socio-economic conditions of the community will facilitate the government or other stakeholders in developing the surrounding community through programs to be implemented. Community development activities will meet the local needs and correspond to their potentials. The activities to obtain this information are 
conducted through socio-economic research using a spatial approach (economic social mapping); it is needed as the approach is more easily understood.

The spatial depiction is a universal technique for representing objects in space. Objects in space are generally represented as symbols. The socio-economic facilities are also represented by symbols on the map. The purpose of this research was to analyze the socio-economic aspects of coastal communities in Klamana Sub-district, East Sorong District, Sorong city, West Papua Province, using the spatial approach. Sorong City, in terms of government administration, consists of 10 sub-districts and 42 sub-districts with land and water area of $1,105 \mathrm{~km}^{2}$, most of which are in the hilly areas. Astronomically, Sorong City is located between 131017 'East Longitude, 0053' South Latitude, and crossed by the equator.

\section{METHODS OF RESEARCH}

This research was conducted in September 2019 in Klamana Sub-district, East Sorong District, Sorong city, West Papua Province. The location is shown in Figure 1. The term 'district' is an administrative term in Papua similar to the sub-district which refers to Law No. 23 of 2014 concerning the Regional Government.

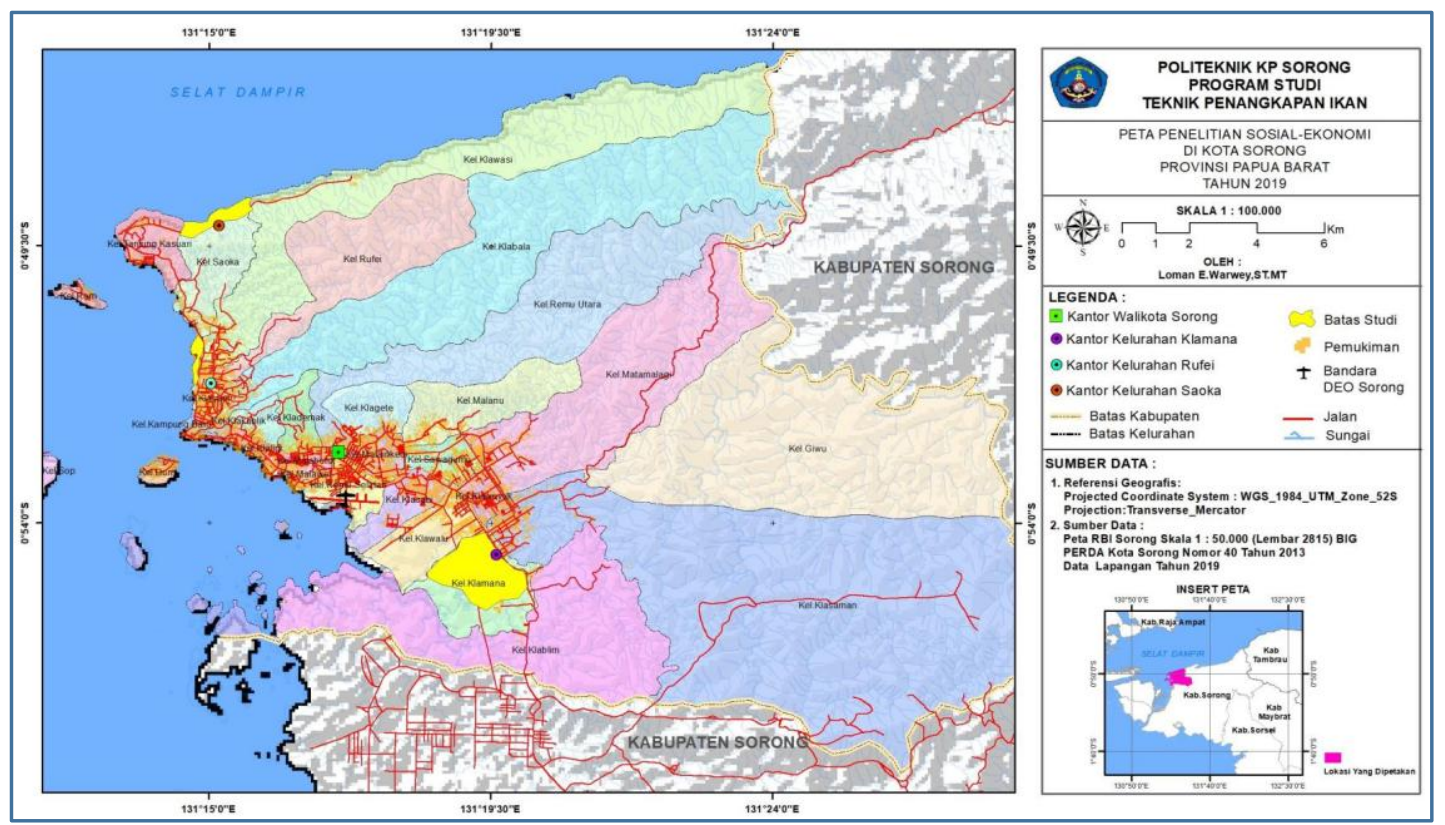

Figure 1 - Research location

\section{METHODS OF RESEARCH}

This is a descriptive study using a spatial approach of which the method employed was satellite imagery interpretation, spatial data processing, and analysis with Geographic Information Systems (GIS). The primary data were the socio-economic conditions of coastal communities, especially in RT 05/RW 10 (RT - Rukun Tetangga - neighborhood; RW Rukun Warga - hamlet) directly adjacent to the mangrove ecosystem in Klamana Sub-district as well as its overall socioeconomic using the satellite image interpretation processed in the ArcGis software. The mapping of socioeconomic facilities was carried out by analyzing the results of primary data inputs focusing on the location of socio-economic facilities with building parcels. Measurement of the accessibility of socio-economic facilities is processed based on the distance and distribution parameters of socio-economic facilities. Accessibility is obtained from primary data during field surveys which were processed by spatial analysis of Euclidean distance. The output of Euclidean distance was processed with raster to polygon tools to find out the number of building plots. The number of buildings at a certain distance with socio-economic facilities was interpreted with color. 
The technique of data collection used were questionnaires, interviews, and documentation. The respondents were 30 coastal residents in RT 5/RW 10, Klamana Sub-district.

\section{RESULTS AND DISCUSSION}

Klamana Sub-district is an area of $24.23 \mathrm{~km}^{2}$ whose borders are the Klasaman Sub-district in the north, the Klablim Sub-district in the south, the Klablim Sub-district in the east, and the Klawalu Sub-district in the west.

The details of administrative borders and overall socioeconomic facilities in Klamana Sub-district are presented spatially as in Figure 2.

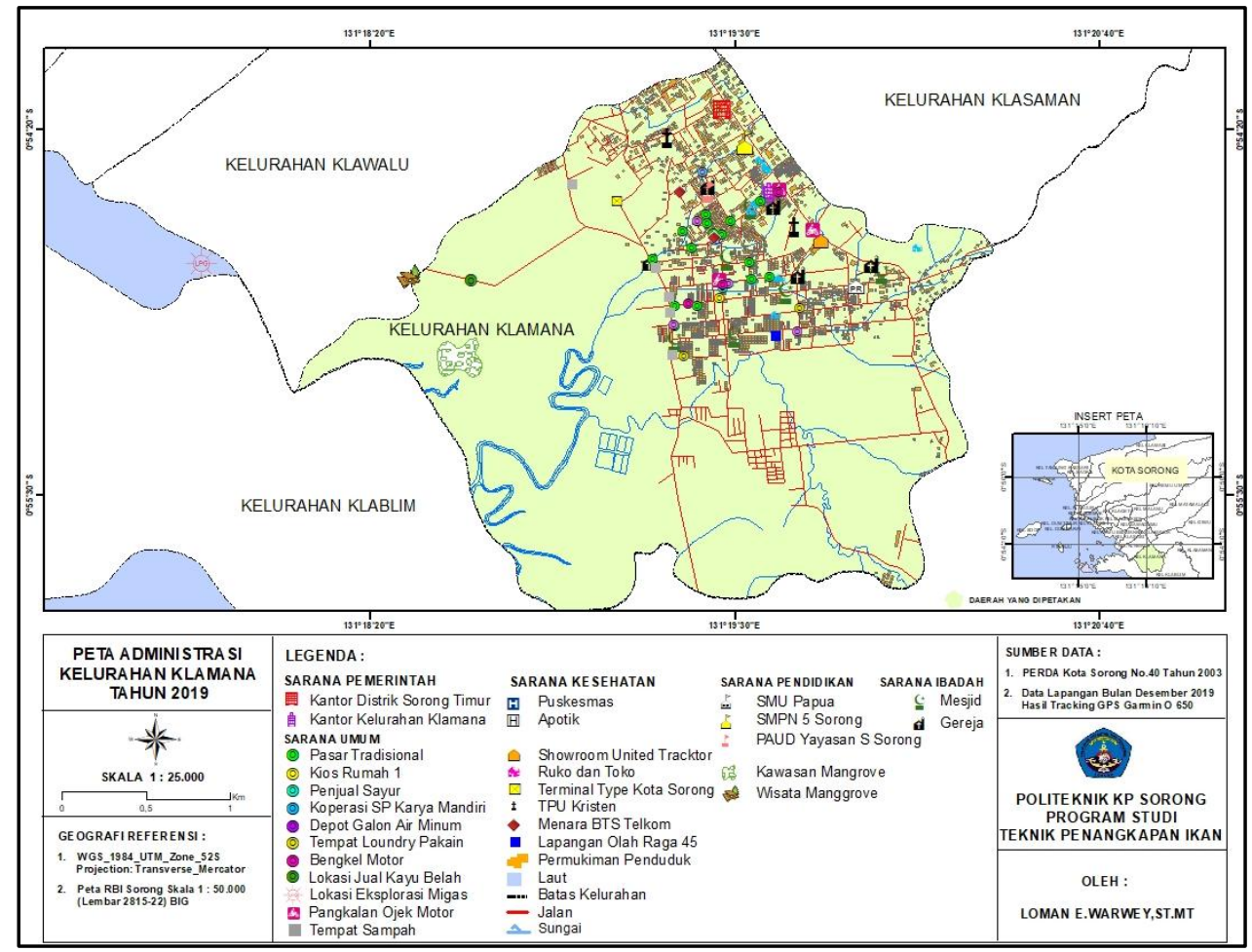

Figure 2 - Administration and socio-economic facilities in Klamana sub-district

The social and economic research objects in the coastal communities included the level of education and income, type of work and socio-economic facilities viz. education, health, government and public services, social economy, trade, and services.

The easiest measurement tool to detect the human resource potential is the level of public education as well as the characteristics and performance of existing educational institutions. Page and Thomas (1977) defines education as a process of developing human capabilities and behavior as a whole.

The education level of the respondents in the Klamana Sub-district residing around the mangrove forest was low as most of them were graduated from elementary school $(55 \%)$ and did not attend formal education/school (16\%); thus, there was a gap in education with other areas, especially in the urban. This is in line with the results of Farida and Andlas' research (2019) concluding that one of the forms of socio-economic inequality representation between coastal and urban communities is education; coastal communities are always dichotomized as poor, ignorant, dirty, subordinate people and low-lives. This is because the development is always oriented and centered on urban communities.

The detailed condition of education level can be seen in Figure 3. The respondents had the opportunity to receive an education because there were adequate educational facilities in 
Klamana Sub-district; however, they could not use the facilities because they did not have the money to pay for school and the children helped their parents earn a living.

Educational facilities in the Klamana Sub-district were distributed from 0-2,700 $\mathrm{m}$ from the community settlements. Educational facilities, the Radius Pencapaian (facilities radius), and the spatial / mapping of educational facilities in the Klamana sub-district are presented in Table 1, Figures 4 and 5.

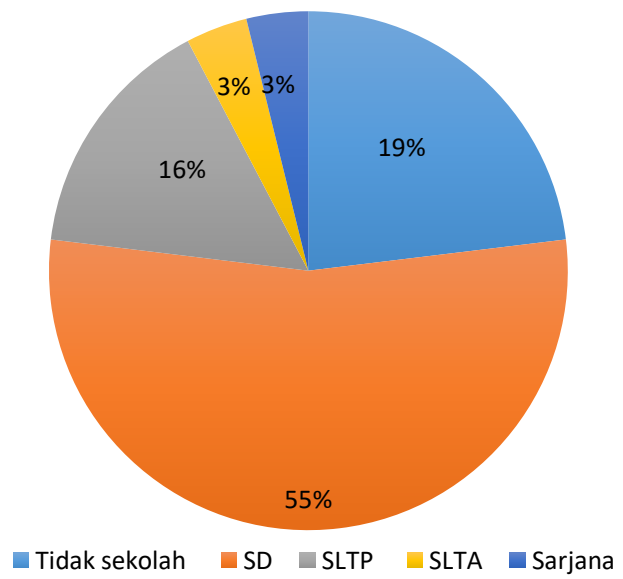

Figure 3 - Community education level diagram

Table 1 - The Radius of educational facilities and community in Klamana Sub-district

\begin{tabular}{|l|l|l|l|}
\hline No & Type of facility & Number & Facility radius $(\mathrm{m})$ \\
\hline 1 & Early Childhood Education & 1 & $0-900$ \\
\hline 2 & Kindergarten & 1 & $0-1000$ \\
\hline 3 & Elementary school & - & - \\
\hline 4 & Junior high school & 1 & $100-2.700$ \\
\hline 5 & High school & 1 & $150-1.400$ \\
\hline
\end{tabular}

Table 3 and Figure 5 illustrate that educational facilities in Klamana Sub-district are easily accessed by the community because they are located near community settlements. The educational facility farthest reached by the community is the junior high school 5 , which is around 2,700 (2.8km). The need for education and learning facilities in Klamana Sub-district conforms with SNI 03-1733-1989 and SNI 03-1733-2004: PAUD (Pendidikan Anak Usia Dini Early Childhood Education and Development (also abbreviated as ECED)) and kindergarten are in the center of community settlements, while junior high school and high school do not always have to be in the center. For people who live near coastal areas around the mangrove ecosystem, reaching educational facilities require urban transportation or motorcycle taxi. However, the financial limitation of the parents and the lack of motivation regarding the importance of education lead to many children not attending school.

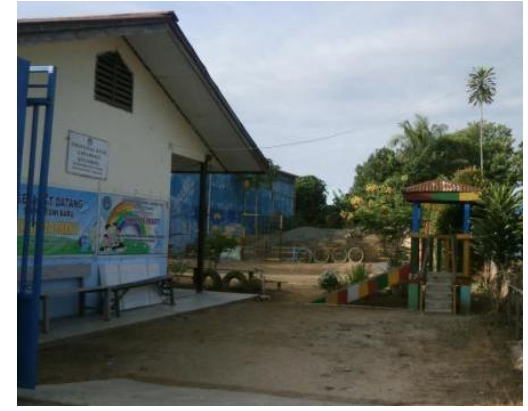

Karya Bakti Kindergarten

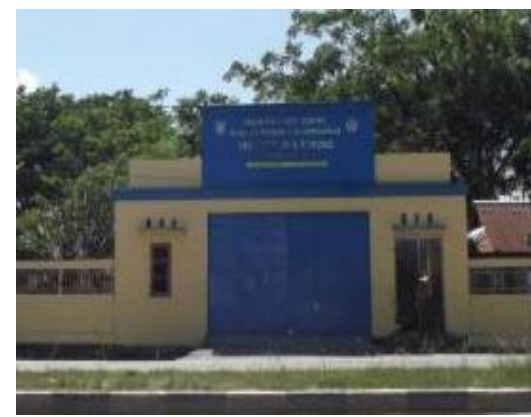

Junior high school 5

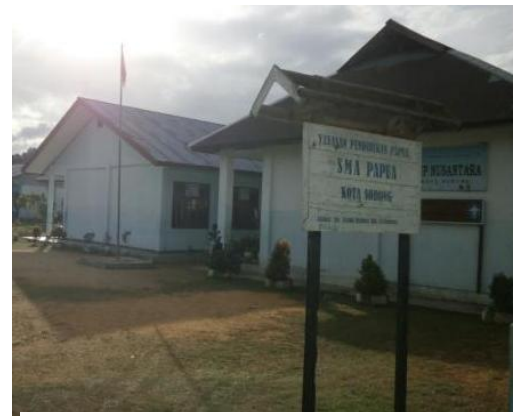

High school of Papua

Figure 4 - Educational facilities in Klamana Sub-district 


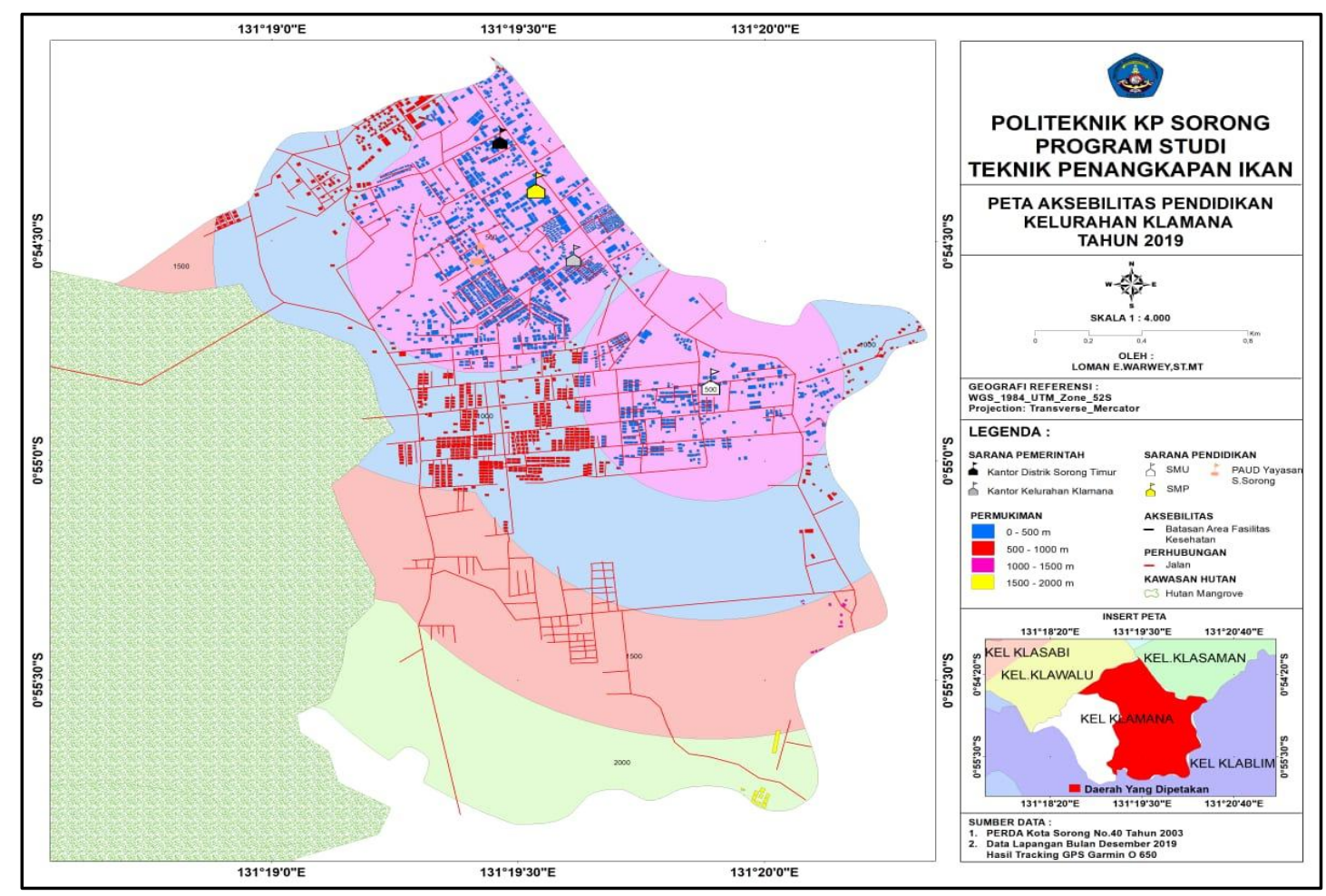

Figure 5 - Educational map of Klamana Sub-district

Household income can be used as an indicator to determine the level of economic progress of households, regions, and programs being run in the region. According to Smith and Skousen (1999), income is the inflows or other additions to the assets of an entity or the settlement of obligations (or a combination of both) originating from the delivery or production of goods, the provision of services, or other activities that constitute the main operation or the ongoing core of an entity.

Based on the results of data collection related to the main livelihood of the respondents' living around mangrove forests, the traditional fishermen using fishing nets (77\%) had an average income of Rp. 1,633,824 / month (Figure 6); so according to the Central Bureau of Statistics, the average income of respondents are categorized as poor (very low) because it is below Rp. 1,999,000. This is not in line with Mulyono's statement (2018) about the poor criteria, which there are two of them: physical (land ownership, homeownership status and assets) and non-physical (work, income, expenditure, potential, and unemployment).

The fishermen's catch was subsistence as they were for sale and daily food. Pollnac (1988) characterizes traditional fishermen using patterns: they operate in small areas, their capacity of fishing gear and fleets used are, for example, oars and outboard motors, and the production is oriented to their own needs.

The low level of community education leads to the alternative of being a fisherman since it does not require formal education. In the windy season, fishermen do not go out to the sea, so they become laborers and small traders; this results in poorer economic conditions. The income of fishing communities is highly dependent on the condition of the aquatic environment and is very vulnerable to environmental damage. Season or weather determines the socio-economic conditions of fishing communities. In fishing season or good weather, fishermen will go to sea, while the famine season decreases their fishing activity; this condition will affect the fishermen's income (Handayani, 2016).

The condition of coastal communities around the mangrove forest needs to receive the local government's attention to improve their welfare and standard of living as they live in an area with adequate and varied economic resources. One of the concepts to develop the life of coastal communities to be more feasible is the business institutional concept; it prioritizes community participation in managing fisheries businesses (Zamroni and Istiana, 2019). 


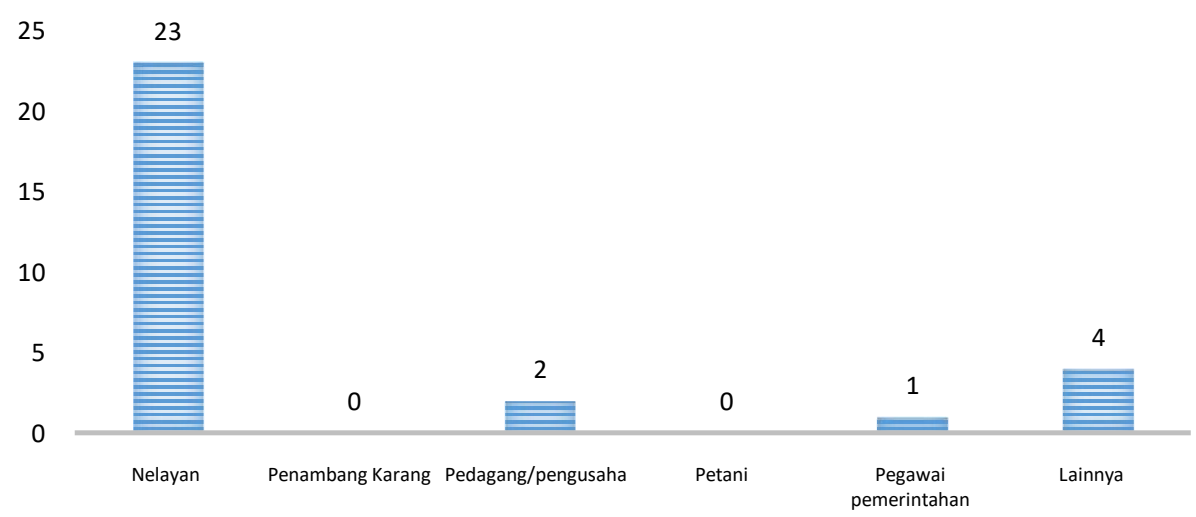

Figure 6 - The main livelihood of the respondents

The economic facilities are the trade and services in the Klamana Sub-district, which among others are: food stalls, kiosks/shops, vegetables stands, traditional markets, and bike shops; these are shown in Table 2, Figure 7, and the spatial/mapping is shown in Figure 8.

Table 2 - Trade and service facilities in Klamana Sub-district

\begin{tabular}{|l|l|l|l|}
\hline No & Type of facility & Number & Facility radius (m) \\
\hline 1 & Food stalls & 2 & $0-900$ \\
\hline 2 & Kiosk/shop & 15 & $0-960$ \\
\hline 3 & Shophouse & 10 & $100-1,000$ \\
\hline 4 & Traditional market & 1 & $50-1,000$ \\
\hline 5 & Bike shop & 3 & $200-1,000$ \\
\hline 6 & A vegetable stand & 1 & $0-1,000$ \\
\hline 7 & Drinking water depot & 4 & $0-1,000$ \\
\hline 8 & Heavy equipment showroom & 1 & $100-1,000$ \\
\hline 9 & Ojek (motorcycle-taxi) station & 3 & $100-1,000$ \\
\hline 10 & Laundry & 2 & $0-1,500$ \\
\hline 11 & Mangrove tourist attractions & 1 & $1.650-3,000$ \\
\hline 12 & Travel and Tour & 1 & \\
\hline 13 & Sand (construction material) dealer & 2 & $100-1,000$ \\
\hline
\end{tabular}

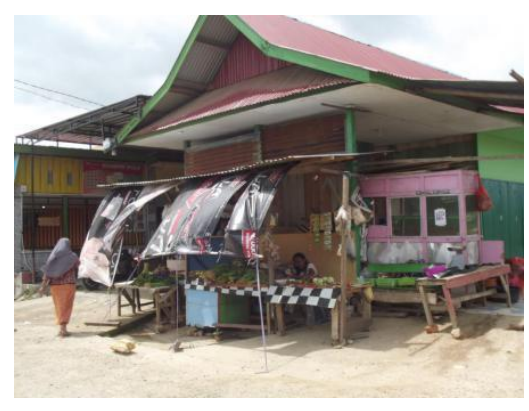

Traditional market

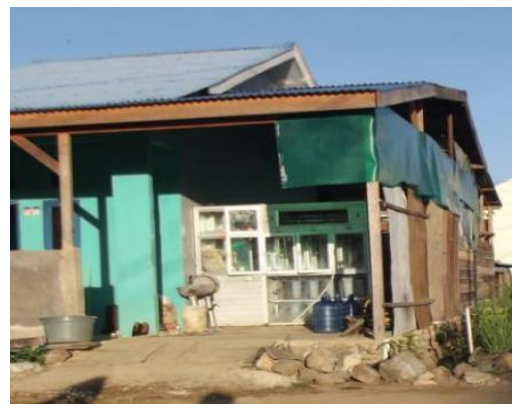

Drinking water depot

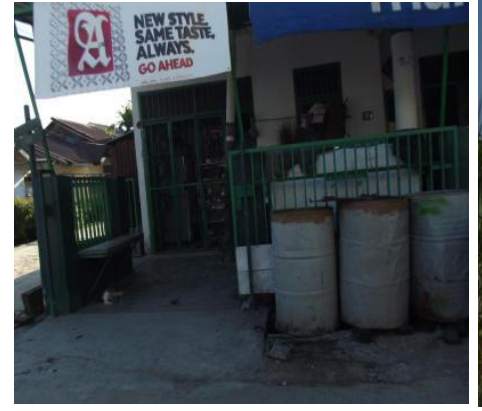

Shop

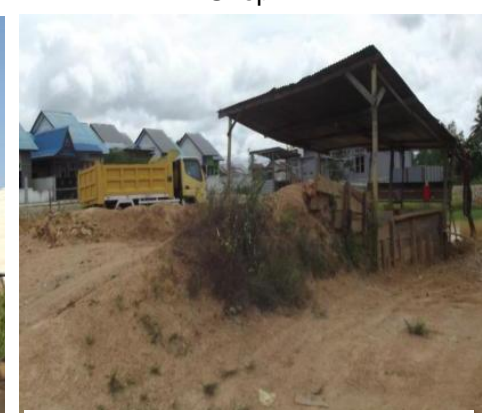

Sand (construction material) dealer

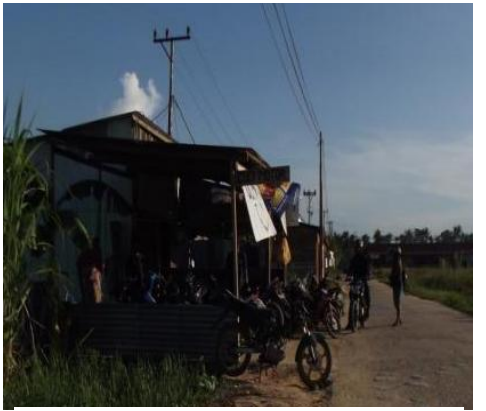

Ojek station

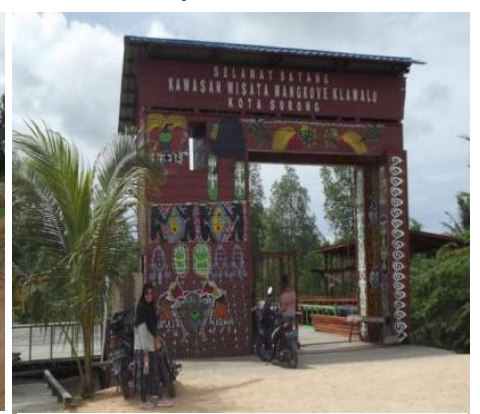

Mangrove tourist attractions

Figure 7 - Trade and service facilities in Klamana Sub-district 


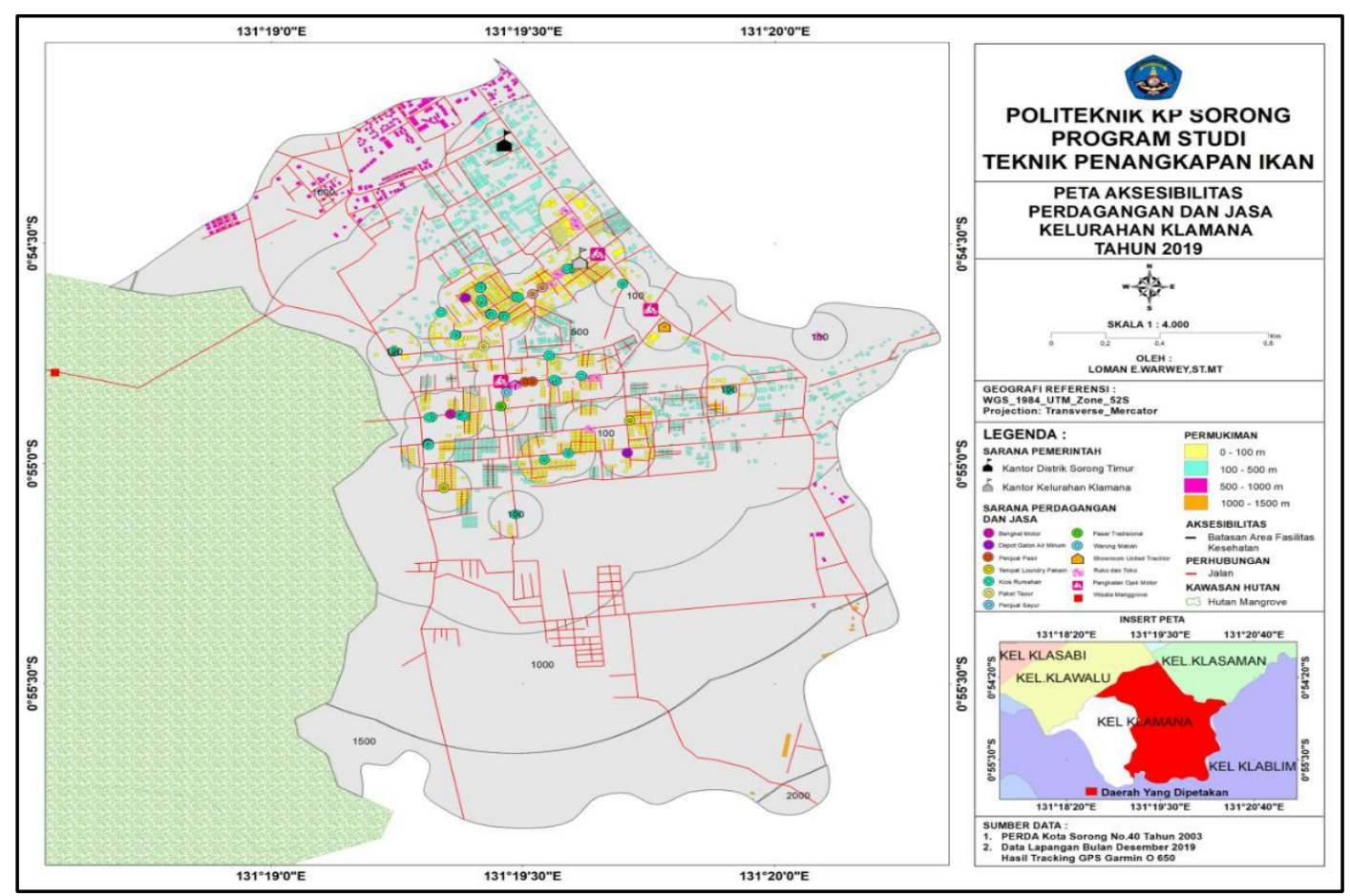

Figure 8 - Map of trade and service facilities in Klamana Sub-district

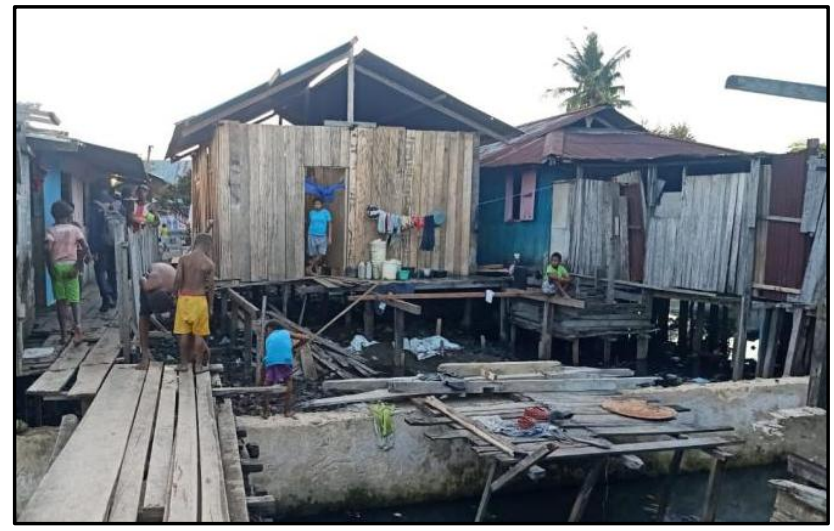

Figure 9 - The non-permanent community house

Communities living in coastal areas have their own characteristics, especially when it comes to health. In general, the coastal community is a traditional fisherman with a mediocre income and is classified as a poor family which affects the availability of family food, as well as decent and healthy houses (Kusnadi, 2003). Observations were conducted at the research location; most of the coastal communities around the mangrove forest have semi-permanent and non-permanent houses. The wall is made of wood, the foundation of the house is made of river stone, and the floor is grounded; the houses built on a mangrove forest floor use wood (Figure 9). The toilet condition is not representative because it is directly discharged to the beach, including other domestic waste.

Unlike the other coastal areas, Klamana Sub-district has a community health center that functions as a first-level health service facility that provides services to residents in healing disease. In addition, there are posyandu (a center for pre- and postnatal health care and information for women and for children under five), and 3 pharmacies that serve the population in the procurement of medicines, both for healing and preventing disease.

The health facilities are adequate and the radius is not far from the settlement; this makes it easier for people who need health services. The types of facilities and the radius, as well as the spatial / health facility mapping, are shown in Table 3, Figures 10, and Figure 11. 
Table 3 - Health facilities in Klamana Sub-district

\begin{tabular}{|l|l|l|}
\hline Type of facility & Number & Facility radius (m) \\
\hline Community Health Center & 1 & $0-800$ \\
\hline Pharmacy & 3 & $0-800$ \\
\hline
\end{tabular}

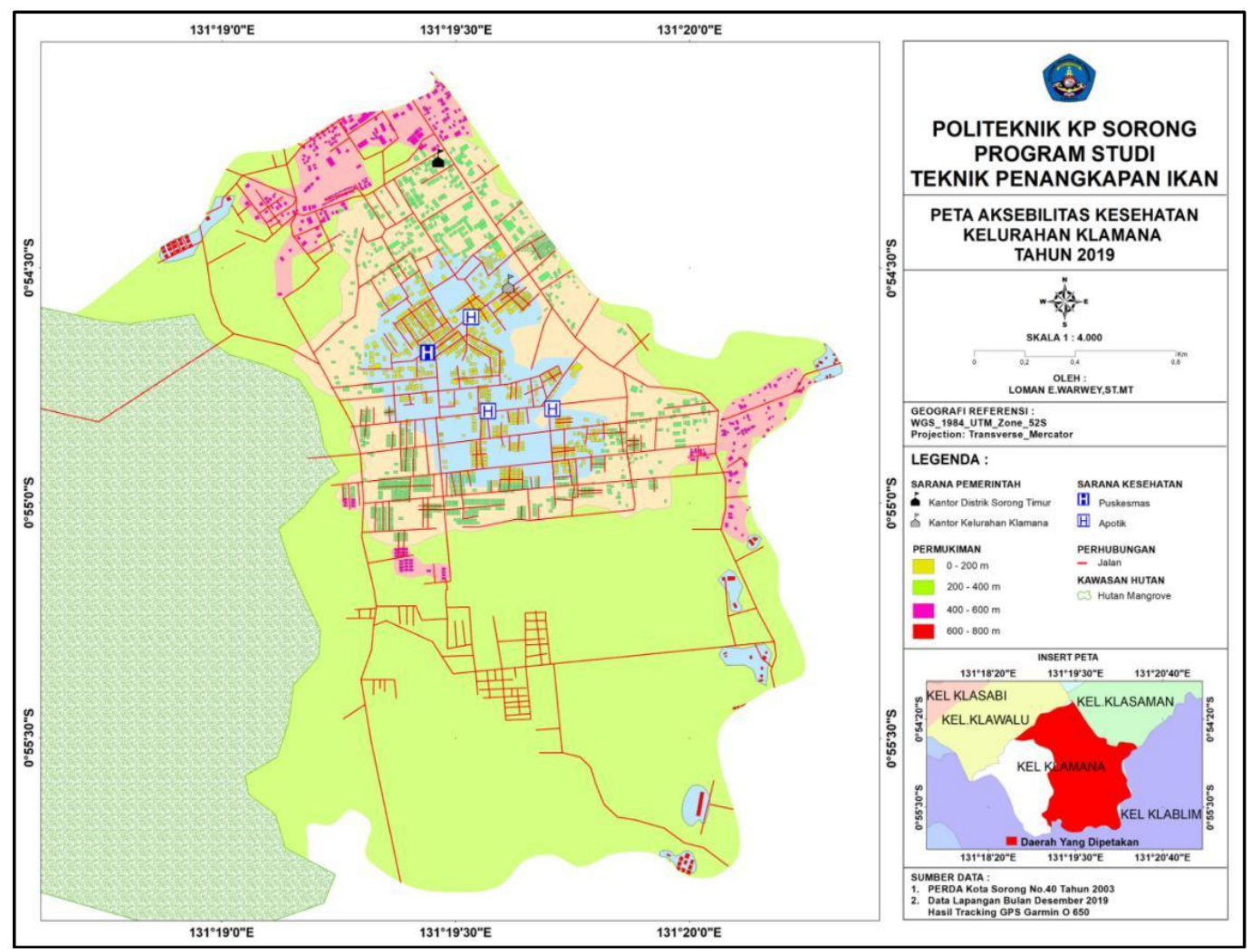

Figure 10 - Health map of Klamana Sub-district

The regional government's attention is needed to provide health education, especially related to clean living. This is according to the mandate of Law No. 21 the Year 2001 Article 38 on Special Autonomy for Papua Province, in which the Regional Government of Sorong City Regency can utilize the West Papua Special Autonomy Fund (Otsus) to create prosperity for all Papuans and West Papuans particularly to fund education, welfare, and health.

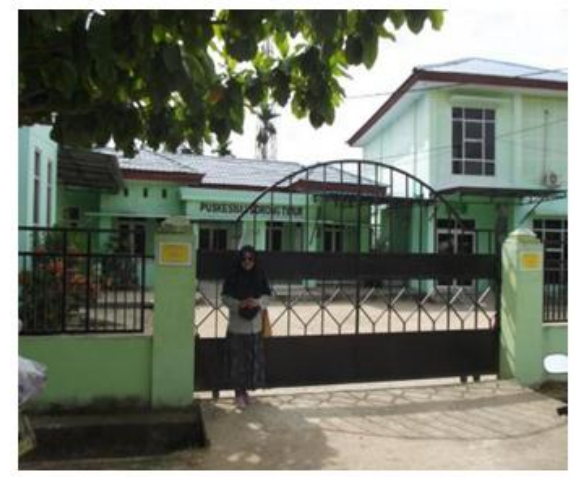

Public health center

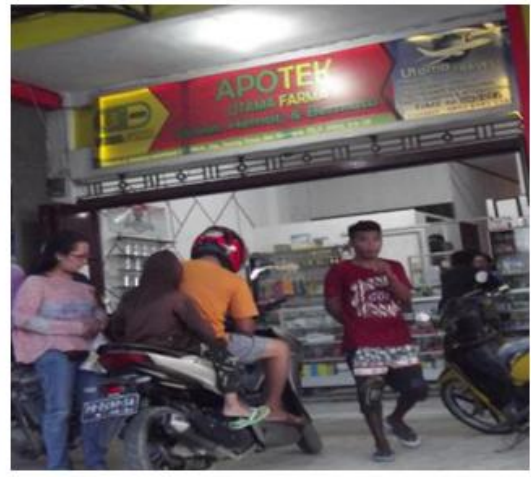

Pharmacy

Figure 11 - Health facilities in Klamana Sub-district

Based on SNI 03-1733-1989 and SNI 03-1733-2004, the need for health facilities is sufficient. This is seen from the radius of the service area i.e. posyandu and pharmacy located in the middle of neighboring groups and can be reachable by vehicles. 
The Klamana Sub-district Office with a radius of $80-900$ meters from community settlements makes it easily accessible to people who need its services. Klamana Sub-district is administratively located in East Sorong District; the location of the East Sorong District office is in the Klamana Sub-district area with a radius of 200-2,000 meters from the settlement. This location is a bit far from some settlements in Klamana Sub-district, but it is reachable because public transportation (angkot) and motorcycle-taxis (ojek) are available.

Table 4 - Government facilities and public services in Klamana Sub-district

\begin{tabular}{|l|l|l|l|}
\hline No & Type of facility & Number & Facility radius (m) \\
\hline 1 & District Office & 1 & $80-900$ \\
\hline 2 & East Sorong District Office & 1 & $200-2,000$ \\
\hline 3 & Saving and loan cooperative & 1 & $50-800$ \\
\hline 4 & Garbage dumps & 5 & $100-1,300$ \\
\hline 5 & Construction of the Type B terminal & 1 & $40-1,400$ \\
\hline 6 & Sports field 45 & 1 & $0-1,570$ \\
\hline 7 & Temporary children's playground & 1 & $0-1,350$ \\
\hline 8 & Mosque / musholla & 6 & $0-640$ \\
\hline 9 & Church & 4 & $0-1,500$ \\
\hline 10 & Christian public cemetery & 2 & $220-1,350$ \\
\hline 11 & Telkom's BTS & 2 & $0-900$ \\
\hline 12 & Security post & 8 & - \\
\hline
\end{tabular}

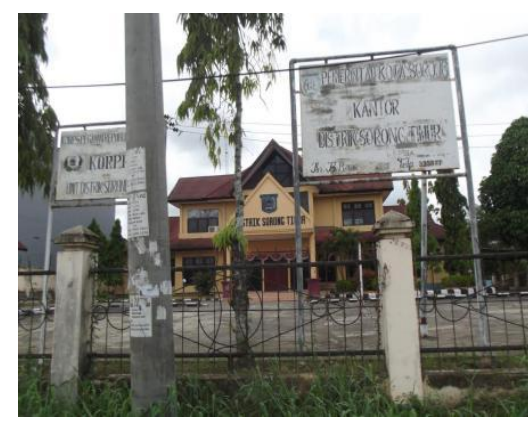

East Sorong District Office

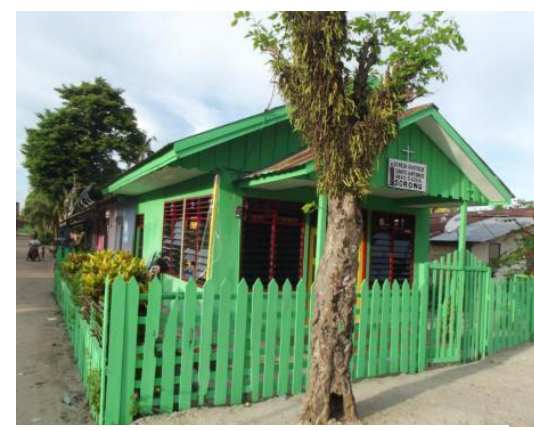

Church

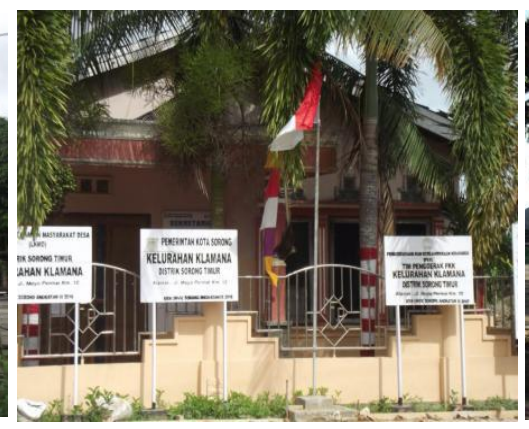

Klamana Sub-district Office

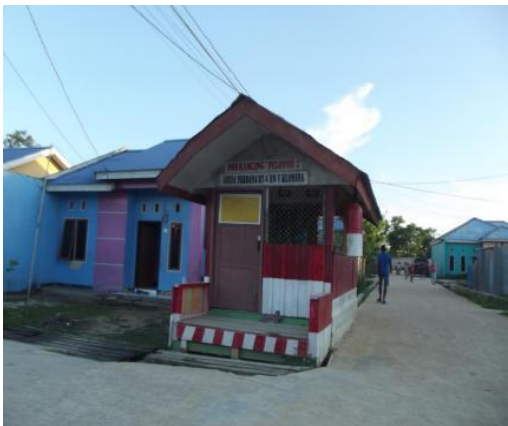

Security post

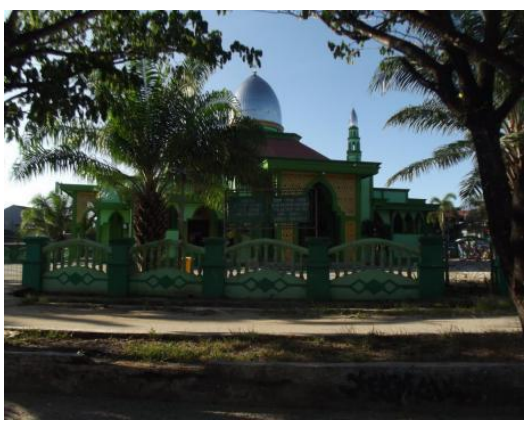

Mosque

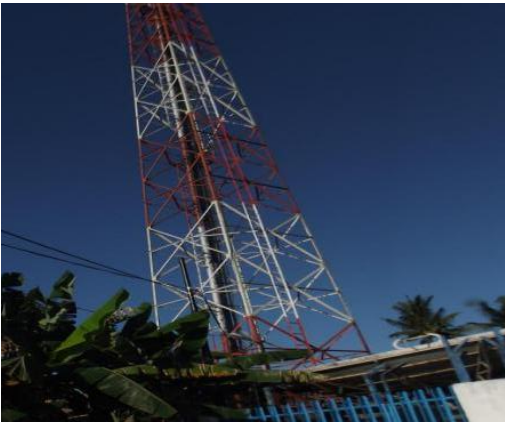

Telkom's BTS

Figure 12 - Government facilities and public services in Klamana Sub-district

Some public facilities are available in the Klamana sub-district area viz. type B terminal (under construction), places of worship (Mosques and Churches), Garbage Disposal Sites (TPS), Public Cemeteries (for Christians), Telkom BTS Towers, Poskamling (security posts) located in every $R T$ / $R W$, as well as sports fields. The details of facilities, and the map of a government facility, as well as public service locations, are presented in Table 4, Figures 12, and Figure 13. 


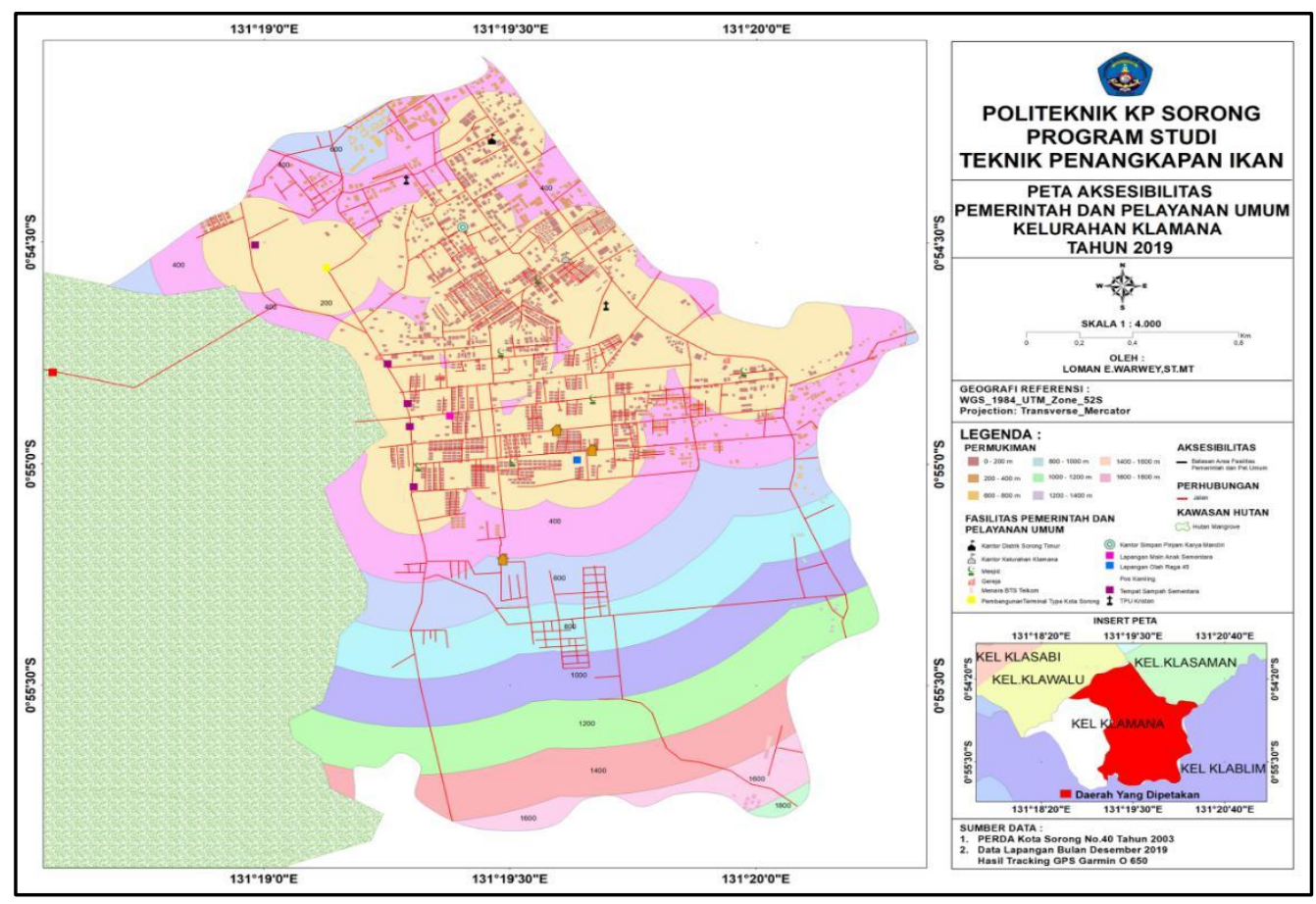

Figure 13 - Map of government facilities and public services in Klamana Sub-district

The worship facilities in the Klamana Urban Sub-district settlement area are adequate as there are 6 Mosques and 2 Churches. The facility radius is in accordance with SNI 03-1733-1989 and SNI 03-1733-2004 stating that the basic needs of the facilities that must be met in fulfilling a sub-district or certain area are placed in the middle of settlements and can be reached by public transportation (or motorcycle-taxis).

\section{CONCLUSION}

The socio-economic conditions of coastal communities, especially those living coexistent with mangrove ecosystems in the Klamana sub-district, show a low education level as $55 \%$ of the community were elementary school graduates. Their main occupation is a traditional fisherman; they use a boat or ketinting fleet and fishing nets. Their average income

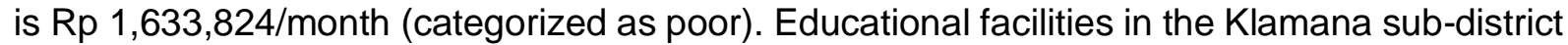
are adequate. However, financial limitations and parents' lack of motivation prevents the children from attending school. The community has not maximized the potentials around them such as economic facilities (trade and services) because the community does not have the ability to create alternative jobs, including maximizing public facilities and services as well as health facilities for the welfare of the community. Therefore, the Regional Government of Sorong City is expected to take part in creating a more viable social-economic life for the community.

\section{ACKNOWLEDGMENTS}

We would like to express gratitude to Loman Efendy Warwey, MT, Taruna Program Studi Teknik Penangkapan Ikan and all communities in the Klamana Sub-district involved in the research. As this research was funded by the Sorong Marine and Fisheries Polytechnic, we were indebted to the Polytechnic Director of KP Sorong.

\section{REFERENCES}

1. Badan Standardisasi Nasional, 2004. Tata cara perencanaan lingkungan perumahan di perkotaan, SNI 03-1733-2004. Jakarta. 
2. Farida, N., \& Andalas, E. F. (2019). Representasi Kesenjangan Sosial-Ekonomi Masyarakat Pesisir Dengan Perkotaan Dalam Novel Gadis Pantai Karya Pramodya Ananta Toer. KEMBARA: Jurnal Keilmuan Bahasa, Sastra, and Pengajarannya, 5(1), 74-90.

3. Handayani, 2016. Prioritas Kebijakan Penyuluhan Perikanan dalam Pengelolaan Lingkungan di KKLD Teluk Mayalibit Provinsi Papua Barat. Disertasi Ilmu Lingkungan. Semarang, Program Pasca Sarjana Universitas Diponegoro.

4. Kusnadi., 2007. Strategi Hidup Masyarakat Nelayan. Yogyakarta: Penerbit LKIS.

5. Mulyono, S. E. (2017). Model pemberdayaan masyarakat miskin melalui jalur pendidikan non formal di Kecamatan Gajahmungkur Kota Semarang. Edukasi, 2(1).

6. Nikijuluw, V.P.H, 2001. Populasi and Sosial Ekonomi Masyarakat Pesisir serta Strategi Pemberdayaan Mereka Dalam Konteks Pengelolaan Sumberdaya Pesisir Secara Terpadu. IPB Bogor: Proyek Pesisir, Pusat Kajian Sumberdaya Pesisir and Lautan.

7. Page, G. T. \& Thomas, J. B., 1977. International Dictionary of Education. London, United Kingdom: Kogan Page.

8. Peraturan Daerah Kota Sorong Nomor 40Tahun 2013 tentang Pemekaran and Pembentukan Distrik and Kelurahan dalam Wilayah Pemerintahan Kota Sorong

9. Pollnac, R.B., 1988. Social and Cultural Characteristics of Fishing Peoples. Marine Behavior and Physiology, 14, pp.23-39.

10. Purba, J., 2005. Pengelolaan Lingkungan Sosial. Jakarta: Yayasan Obor Indonesia.

11. Satria, A., 2002. Pengantar Sosiologi Masyarakat Pesisir. Jakarta: PT. Pustaka Cidesindo.

12. Satria, A., 2009. Ekologi Politik Nelayan. Yogyakarta: PT. LkiS Printing Cemerlang.

13. Smith, J. M. \& Skousen, K. F., 1999. Intermediate Accounting. Ohio, USA: South-Western Publishing.

14. Undang-undang Republik Indonesia Nomor 21 Tahun 2001 Pasal 38 tentang Otonomi Khusus Bagi Provinsi Papua

15. Undang-undang Republik Indonesia Nomor 23 Tahun 2014 tentang Pemerintahan Daerah

16. Wahyudin, Y., 2003. Sistem Sosial Ekonomi and Budaya Masyarakat Pesisir. Bogor: PKSPLIPB.

17. Zamroni, A., \& Istiana, I. (2019). Membangun Kemitraan and Kelembagaan Ekonomi Masyarakat Pesisir Melalui Klinik Iptek Mina Bisnis Di Kabupaten Takalar. Buletin IImiah Marina Sosial Ekonomi Kelautan and Perikanan, 3(2), 53-60. 